\title{
Institutions and Mechanisms for Internal Conflict Resolution: Legal and Non-Legal Means in Resolving Dispute and Attaining Justice in Malaysia
}

\author{
Khairil Azmin Mokhtar
}

DATA NASKAH

Masuk: 25 Januari 2016

Diterima: 21 November 2016

Terbit: 8 Desember 2016

KORESPONDEN PENULIS: Ahmad Ibrahim Kulliyyah of Laws, International Islamic University Malaysia

P.O. Box 10, 50728 Kuala Lumpur kamokhtar@iium.edu.my

\section{ABSTRACT}

Among the questions that the research seek to tackle is should the court become the only saviour of justice? In this article it is argued that the task to combat injustices, produce a just ordering of society, ensure a fair distribution of material and legal resources, safeguard the rule of law, promote equality, ensure proportionality in punishment, and protect entitlements and legitimate expectations should not be put on the shoulders of judges and courts only. It must be spread out and shared by other institutions and by whatever means available. This article seeks to establish that in spite of the crucial role of the court in establishing justice, there are other institutions and mechanisms that can and have been used to achieve justice. In this study Malaysia is used as an example. This article is the result of a qualitative study which employs legal analysis of the constitution and laws in the country. Despite the judiciary's fundamental role in dispensing justice it have weaknesses and limitations. As shown in this article apart from the formal courts and judges there many institutions and mechanisms which are outside the formal structure of the judiciary that play significant role in resolving dispute, avoiding conflict and realizing justice. As can be observed in this study the role of these institutions becomes more crucial and important especially when the integrity and credibility of the court or judges are questioned and doubted by the public.

Keywords: Legal Means, ADR (Alternative Dispute Resolution), Conflict, Justice, Peace

\section{ABSTRAK}

Penelitian menjawab pertanyaan apakah pengadilan hanya satu-satunya cara untuk menyelamatkan keadilan. Tulisan berargumentasi tugas untuk melawan ketidakadilan, mewujudkan masyarakat yang berkeadilan, menjamin distribusi ekonomi, menjamin rule of law, mempromosikan persamaan, menjamin adahnya hukuman yang proporsional, dan 


\section{MEDIA
HUKUM}

melindungi harapan masyarakat tidak harus melalui institusi peraadilan. Di dalam artikel ini dibahas bahwa di samping peradilan, masih ada mekanisme lain yang dapat digunakan untuk mencari keadilan hukum. Artikel ini akan menggunakan Malaysia sebagai contoh dalam penggunaan mekanisme di luar pengadilan, yaitu alternative dispute resolution. Penelitian ini merupakan penelitian normatif dengan menggunakan analisis yang bersifat kualitatif terhaddap konstitusi dan peraturanperundangan yang ada di Malaysia. Penelitian ini menunjukkan bahwa penyelesaian sengketa melalui pengadilan, dalam hal tertentu, memerlukan prosedur yang panjang dan memiliki keterbatasan. Oleh karena itu, penyelesaian sengketa melalui mekanisme di luar pengadilan menjadi alternatif yang dapat digunakan mencari keadilan. Penyelesaian sengketa melalui mekanisme alternatif di luar pengadilan faktanya menjadi krusial di tengah rendahnya tingkat kepercayaan masyarakat terhadap institusi formal peradilan yang ada. Kata kunci: penyelesaian hukum, alternative disputes resolution, conflict and justice

\subsection{INTRODUCTION}

Seeking justice is a noble cause and dispensing justice is an obligation that the state must fulfill. Under the doctrine of separation of powers courts exist to protect people and their rights, to guarantee fairness and justice for all. The task to combat injustices, produce a just ordering of society, ensure a fair distribution of material and legal resources, safeguard the rule of law, promote equality, ensure proportionality in punishment, and protect entitlements and legitimate expectations should not be put on the shoulders of judges and courts only. It must be spread out and shared by other institutions and by whatever means available.

In all social systems, the formal, enacted, written law of the state co-exists with a large corpus of non-state law. On the same note there are various institutions and processes which exist that could be used to resolveinternal/domestic conflicts and promote peace. In addition to formal means of resolving disputes, namely through adjudication or litigation, and well established alternative disputes resolution methods, such as arbitration and mediation, there is a wide range of other means for coping with various types of con- flicts. Seeking justice is a noble cause and dispensing justice is an obligation that the state must fulfill. Under the doctrine of separation of powers courts exist to protect people and their rights, to guarantee fairness and justice for all. Among the questions that the research seek to tackle is should the court become the only saviour of justice? What is the alternative if the court is not trusted by the people? Could there or should there be other institutions that upheld and dispense justice? In this article it is argued that the task to combat injustices, produce a just ordering of society, ensure a fair distribution of material and legal resources, safeguard the rule of law, promote equality, ensure proportionality in punishment, and protect entitlements and legitimate expectations should not be put on the shoulders of judges and courts only. It must be spread out and shared by other institutions and by whatever means available.

This article is the result of a qualitative study which employs legal analysis of the constitution and laws in the country. In this article initially various methods for resolving disputes are mentioned and explained. Subsequently the numerous mechanisms, institutions and bodies which are available to be used in solving disputes within Malaysia's legal and constitutional framework are discussed. This article seeks to establish that in spite of the crucial role of the court in establishing justice, there are other institutions and mechanisms that can and have been used to achieve justice. In this study Malaysia is used as an example. The role of these institutions becomes more crucial and important especially when the integrity and credibility of the court or judges are questioned and doubted by the public.

\subsection{THE RELATIONSHIP BETWEEN LAW, CONFLICT, DISPUTE RESOLUTION AND ALTER- NATIVE DISPUTE RESOLUTION}

Conflict is inevitable and perpetual in all human interaction. "Human beings engage in conflict. Aggression, warfare, violence seemingly equate with the human condition" (Tidwell, 1999: p1.). Conflict requires rules to ensure that justice prevails and truth is pursued (Alan Simpson, www.mediate.com). One of the main functions of law is to establish "rules and procedures that constrain the power of all parties, hold all parties accountable for their actions, and 
prohibit the accumulation of autocratic or oligarchic power. It provides a variety of means for the non-violent resolution of disputes between private individuals, between groups, or between these actors and the government" (Crocker \&Hampson, 1996: p. 586.).

Dispute resolution, in its most basic form, is the process of finding a solution to a point of contention between two or more parties or individuals. In the legal sense, dispute resolution includes specific methods of resolving disputes, such as through lawsuits, through arbitration and through mediation. A lawsuit (adjudication) is the most formal legal method of resolving a dispute. Generally, alternative dispute resolution (ADR) refers to any process or collection of processes established to resolve disputes without trial or violence. The term "ADR" is often used to refer to a broad category of "ADR processes" such as negotiation, conciliation, mediation, settlement conferences, arbitration, consensus building, and community conferencing.

All kinds of disputes may be resolved under three general categories: the unilateral mode, the bilateral mode and the third party intervention mode. Unilateral Mode, as the term indicates, is an action that is taken by one of the disputants without regard to the wishes of the other party. This could take the form of fight, flight or surrender, and forgiveness. At the micro level, the more aggressive party can take some violent action against the other, to cow the latter into submission. Bilateral mode means direct negotiations between the disputants to arrive at a settlement of the dispute between the parties that could be mutually beneficial. The result at the micro level is a compromise agreement. At the national level, the result could be a peace pact to end a rebellion. This could be the beneficial result of bargaining on the basis of interest and principle, not on hard and fast position.

The concept of law is the tree trunk on which adjudication and facilitation theories and practices branch out. The role of law is to nurture and channel the development of how people and groups of people manage conflict. In other words, law is the banks on either side of the river of the varieties of dispute resolution. "The Law is often thought of as being the guardian of our liberties, and rightly so" (Leiser: 1973: p. 1.). Pirie suggests that "ADR [Alternative Dispute
Resolution, which encompasses the many approaches to facilitation] is not a new idea but rather a modern reflection of the legal profession's long standing support for quality legal services" (Pirie, 2000: p. 35.). This explanation suggests that adjudication and facilitation/ADR stem from the same tree and flow in the same water. They are both aiming to bring accountability and common good into the realm of conflict management (Alan Simpson, http:// www.mediate.com).

\subsection{LEGAL MEANS IN RESOLVING DISPUTES}

This category refers to the methods which involved legal power which are binding and legally enforceable.

\subsection{Litigation/(Court Based) Adjudication}

The "conventional" model of dispute resolution is one of an adjudicative process, most frequently fulfilled by the courts. The ideal court, or more properly the prototype of the court involves 'an independent judge applying pre-existing legal norms after adversarial proceedings in order to achieve a dichotomous decision in which one of the parties was assigned the legal right and the other found wrong."(Schapiro, 1981).

Adjudication generally refers to processes of decision making that involve a neutral third party with the authority to determine a binding resolution through some form of judgment. A lawsuit is the most formal legal method of resolving a dispute. In order to bring a lawsuit against another party, an individual must file a complaint that contains an actionable claim. Actionable claims are disputes that the body of laws in a jurisdiction can resolve. For instance, a dispute regarding the terms of a contract is an actionable dispute because laws, statutes, regulations and codes exist to resolve these types of issues.

Filing a lawsuit against someone because they happen to like one color over another, for example, is not an actionable claim, because no legal remedies exists on that issue. Lawsuits are decided either by a judge or by a jury. During a lawsuit, both sides to the suit present evidence and witnesses to persuade the judge or jury to rule in their favor. After a final ruling is made on the issue, the dispute is resolved, unless one of the parties chooses to appeal the rul- 


\section{MEDIA
HUKUM}

ing to a higher court.

Adjudication is an involuntary process, in the sense that a court has the power (once its jurisdiction is properly invoked by a plaintiff) to coerce a defendant into either participating in the process or suffering the consequences of a default judgment. The judge, a neutral third-party appointed by the state, has the power and responsibility to run the proceedings and to resolve the dispute (Robert H. Mnookin, Alternative Dispute Resolution, http:// www.law.harvard.edu). It is also an adversarial process. This means arguments are presented to prove one side right and one side wrong, resulting in win-lose outcomes. The disputants hire lawyers to act as their advocates and the case is argued before an impartial and neutral third party a judge. During a lawsuit, both sides to the suit present evidence and witnesses to persuade the judge to rule in their favor.

The judicial proceedings are highly structured, with formal rules governing pre-trial discovery and the trial itself i.e. what counts as evidence, the order in which evidence is presented and how arguments are made. In reaching its decision, the adjudicator is responsible for making a principled and reasoned decision based on legal norms. The trial judge's decisions are binding on the parties, subject to appeal to a higher court. Finally, adjudication is a public process - the judge is a public official, and the proceedings themselves are ordinarily open to the public and not confidential (Robert H. Mnookin, Alternative Dispute Resolution, http://www.law.harvard.edu).

The decision maker takes into consideration not only the disputants' concerns, interests, and arguments but also the broader society's standards and values. The judge is usually required to make a decision based on and in conformity with case law and legal statutes. The outcome is usually win-lose. Because the third party is socially sanctioned to make a decision, the results of the process are binding and enforceable.

The protections offered by litigation may be uncertain. Formal justice is expensive and access may depend on the capacity of the parties to pay for it. Further, the protections provided by the formal justice system make it expensive and slow. Whilst litigation has many problems as a dispute resolution mechanism, it nevertheless contains many safe- guards of fairness and justice. Power imbalances between the participants can be ameliorated by legal representation. Procedural and evidentiary rules ensure that each person has a chance to present their case and to challenge the arguments and evidence of the other person. There are enforceable procedures which ensure that each person has access to relevant evidence so that the dispute is decided on the basis of appropriate disclosure of information. There is a well qualified and respected third party decision maker who evaluates the evidence and arguments of the parties and who makes a decision according to established principles. The process of litigation is open and observable and decisions are subject to appeal (National Alternative Dispute Resolution Advisory Council, https://www.ag.gov.au.).

\subsubsection{Litigation/ (Court Based) Adjudication in Malaysia}

Malaysia applies the English common law system and its court system is based on the English Judicial hierarchy, with the highest court being the Federal Court. Below it are the Court of Appeal, two High Courts (Malaya, and Sabah and Sarawak), Sessions Courts, and Magistrates' Courts. The jurisdiction of each Court is clearly defined by statute, as well as the Federal Constitution.

This method of resolving problem currently faces many problems and challenges. The main problem facing the court system is the backlog of cases. Another is delay caused by lawyers or prosecutors in getting their cases ready for trial. Due to frequent postponement of cases, cases which could have been disposed of remained in the court registry files as active cases. Judges and magistrates are subject to transfer, and when this happens many "part-heard" cases emerge. The same Judge needs to be available to continue with his or her case in the old locality while at the same time, he would have to manage the cases which are filed in court in the new locality. Hearing dates therefore are liable to be postponed, and this will prolong the trial process.

Usage of the courts require strict adherence to Rules of procedure, be it civil or criminal procedure also becomes a source of problem. Most of these rules are not easily understandable by the common man, and as such, lawyers are required to help the layman to file his case in court; to draw 
up a statement of claim or defense; to file affidavits; to make sense of the legal language used in most commercial contracts, and finally, to argue the case before the magistrate or Judge. Furthermore court proceedings are very formal, often time-consuming, and expensive (due to legal costs). The atmosphere is not "friendly" as litigation is adversarial in nature.

\subsection{Legislative Decision / Constitutional}

\section{Amendment}

The legislative approachto dispute resolution is another public means of solving a conflict by recourse to law. In this approach, the decision regarding the outcome is made by another win-lose process: voting. The individual has only as much influence on the final outcome as he or she, and those who share his or her beliefs, can bring to bear on legislators. Furthermore, the win-lose aspect of the outcome is only partly softened by the compromises that go into a bill.

It is usually employed for larger disputes affecting broad populations, but it may have significant utility for individuals. Parliaments have a crucial role in conflict prevention, resolution and maintenance of peace. First and most importantly, Parliaments should first demonstrate their own commitment to "non- militaristic" conflict mediation/ resolution. Political will and commitment to address both substantive and emotional dimensions of conflicts are crucial elements if conflict mediation/ resolution interventions are to be effective. The priority is to bolster legislatures/ parliamentary capacity and develop proactive legislative-civil society based "non-militaristic" conflict mediation/resolution and post-conflict reconstruction interventions.

Efforts to resolve and transform violent conflict can only be effective in the long- term, when based on active participation of all segments of civil society. Catalytic processes on legislative-constituent interaction in order to stimulate national level awareness of co- existence, tolerance and reconciliation, has an extremely important spin- off effect for conflict mediation/resolution and peace building. Parliamentarians provide this extra impulse on conflict mediation/resolution by stimulating forums, agenda setting and constitu- ency building on conflict resolution. Ensuring that bottomup as well as top-down constructive ideas at all levels are heard and incorporated into conflict mediation/ resolution initiatives becomes very fundamental.

Equally important is the horizontal transfer of knowledge and experience among Parliamentarians within the region on peace building. Those within the region who have developed broad consensus on strategies and related set of interventions to their conflicts are been tapped to assist other Parliamentarians. Learning from each other's experiences inspires innovative approaches and helps in breaking the logic of war. In order to maximize the benefits of common norms at national/ local level there is need for Parliaments to involve and engage as many people and sectors of society, along with long- term strategic partnering, reaching across the dividing lines of conflict in society. This is because conflict mediation/resolution and peace building cannot be built just through exclusive conclaves of the leaders of the conflicting parties (KasukaMutukwa, Parliament's Role In Conflict Mediation/Resolution, Policy Dialogue On Legislative Development, Brussels:2002).

\subsubsection{Legislative Decision/ Constitutional Amendment in Malaysia}

Legislation and constitutional amendment at the national level in Malaysia is done by the Parliament and at the state level by the respective state legislative assemblies. These bodies which mainly comprised of elected representatives have the role of representing the people.Malaysia can be proud that since independence, thirteen general elections have been held and the electoral exercise has never been delayed. The Federal Government's right to rule is derived from its ability to command the confidence of the majority in the Dewan Rakyat in the Parliament. The PM must belong to the Dewan Rakyat but other Cabinet Ministers may belong to either House (Article 43(2) of the Federal Constitution of Malaysia.). If the PM loses the confidence of a majority of the members of the Dewan Rakyat, then he and his entire Cabinet must resign.

In constitutional theory, legislation at the federal level is the function of Parliament. Whether it is an ordinary law under Articles 66-68, a constitutional amendment under 


\section{MEDIA
HUKUM}

Articles 159 and 161E, or an emergency Act under Article 150(5), no legislative proposal can become law without going through the fires of scrutiny in both Houses of Parliament.

Members of Parliament are not only legislators; they are problem solvers, social workers and spokespersons for their areas. To the chagrin of some MPs, a large amount of their time is spent on particularized demands of their constituents.

The Dewan Negara which is a component of Parliament also represents the states: It gives to each state, whether big or small, equal representation. It has 26 State Senators - two from each state, indirectly elected by the state legislatures. It also represents special groups. The Dewan Negara has 44 Senators appointed by the Yang di-PertuanAgong on the advice of the Prime Minister. These Senators are supposed to represent various sectors of the population including the professions, racial minorities, women and orang asli (Article 45(2) of the Federal Constitution of Malaysia).

The Public Accounts Committee is a Dewan Rakyat Committee - emphasizing the Dewan Rakyat's pre-eminent role in the raising and spending of money. In addition to passing legislation, Parliament remains informed about matters of national expenditure through the Dewan Rakyat's Public Accounts Committee (PAC). The Committee relies heavily on the Auditor-General's annual admonishments of departments that fail to live up to financial prudence. How effective the Auditor-General and the PAC are in enforcing financial prudence is, however, a matter of great debate.

\subsection{FORMAL NON-LEGAL MEANS}

This category refers to methods in resolving disputes which involved authoritative power but do not go through usual legal channel through the courts and legislatures.

\subsection{Administrative Decision, Inquiry and}

\section{Ombudsman}

If the dispute is within an organization or, occasionally, between an organization and members of the public, there is often an administrative or executive dispute resolution approach. In this process, a third party who has some dis- tance from the dispute but is not necessarily impartial may make a decision for the parties in dispute.

The process can be private, if the context within which the dispute occurs is a private company, division, or work team; or public. If the difference is a public dispute and is conducted by a governmental agency, a mayor, a county commissioner, a planner, or another administrator. An administrative dispute resolution process generally attempts to balance the needs of the entire system and the interests of individuals or concerned groups.

Ombudsman originated from a Swedish word that means a defender or agent. It is also known with many other different terms like Parliamentary Commissioner, Human Rights Mediator and others. Even though the terminologies differ, the concept that is introduced is the same, which is to observe the actions of the authorities and improve any defects in an unfair administration towards the people. It can be defined as "a department or a body instituted through the constitution or the legislative assembly or the parliament headed by a high ranking public officer who is nonpartisan who can be responsible to the legislative assembly or the parliament, who accepts complaints from anyone who has grievances against any agencies, officers and employers, or those who act independently to investigate and recommend solutions to improve the situation and produce reports". Ombuds Offices provide a confidential, neutral and informal process for people in conflict. The ombudsperson may provide advice about resolving the conflict and may help arrange for the people in conflict to use any of the above- mentioned ADR services. The ombuds usually reports to the highest ranking official in an organization, provides statistical data on service delivery, and makes recommendations for systemic changes aimed at preventing and managing conflict (Conflict Resolution Terms and Processes. http://www.acrnet.org).

An instrument used in modern administrative processes is that of holding inquiries. It is a feature of modern democratic governments that inquiries are from time to time conducted into matters of public importance. Such inquiries are not judicial proceedings but are in the nature of fact finding exercises. Commissions are ordinarily appointed at times of grave public disquiet about some aspect of gov- 
ernment or some problem of widespread public concern. In times of such crises the normal investigatory procedures and judicial inquiries may seem inexpedient and inappropriate. This is so particularly where there are political ramifications and where the conduct of public officials is at issue. If the matter requires special expertise (such as for example, an inquiry into the financial system or into the practices of a particular trade) there may be no feasible alternative to a Commission proceeding.

Commissions of Inquiry have the power to take evidence upon oath and to call for persons and documents. Their authority is protected by rules regarding contempt. But they do not make conclusive or binding decisions. Usually, they would report on facts found in investigations and make recommendations for remedial actions. The scope of their inquiries would be determined by the specific terms of reference. The finding and reports are meant to assist the appropriate organs of government to take further action under the law. Inquiries differ from tribunals, for while evidence may be tendered and received by both, a tribunal makes a decision by itself, but in an inquiry, the inquiry officer does not make any decision; the officer reports findings to some higher administrative authority which makes the decision on the action to be taken.

\subsubsection{Administrative Decision, Inquiry and Ombudsman in Malaysia}

Courts have lost their monopoly of the adjudicatory function and have come to share it with administrative bodies including tribunals. A number of bodies have been established by statutes outside the judicial system which decide questions of fact as well as law and determine a variety of claims, controversies and disputes not only between an individual and a department — but also between individuals.

There are administrative agencies other than the courts to adjudicate such issues arising in the course of day to day administration. Administrative adjudication is the resolution of quasi-judicial matters by administrative agencies or commissions established for the purpose. These administrative agencies with the power to adjudicate the disputes arising out of administrative action or inaction are called administrative tribunal. A tribunal is a body set up by legislation to adjudicate upon disputes in a specific area, enjoying a degree of autonomy.

Such tribunals seem to constitute the best mechanism to settle disputes outside the court system because they enjoy some element of separation and independence from the administration and are near the model of a court and appear to share its authority.

A number of technical issues and disputes emerge in the day-to-day administration. The ordinary courts do not have the technical expertise and it becomes quite dilatory and costly to dispense with cases of administrative nature. It is only the administrative agencies, which are capable of looking into the matters of administrative exigencies.

Specialised tribunals to deal with specific disputes had been established in Malaysia long before the problems with the court system surfaced. These tribunals are established as courts or centres of arbitration. Examples of these bodies are the Kuala Lumpur Regional Centre for Arbitration (established in 1978), the Industrial Court (first established actually in 1948) and the Special Commissioners of Income Tax (established under the Income Tax Act, 1967). Other more recent statutory tribunals or adjudicatory bodies include Professional Disciplinary Bodies, Rent Tribunal, Social Security Appellate Board, Commission for Workmen's Compensation, Commodities Trading Tribunal, Appeal Board for Planning Matters, Registrar of Trademarks, Collector under the Land Acquisition Act and Registrar of Societies, Licensing Authorities.

There are adjudicatory functions discharged by Ministers. Most of the adjudicatory powers given to Ministers are of an appellate nature, the usual pattern being that a decision is taken in the first instance by an administrative official or authority, and then an appeal there from lies to the concerned Minister whose decision is invariably declared by law to be final. For instance under the Entertainment (Federal Territory of Kuala Lumpur) Act 1992 (Act 493) in relation to cancellation of a licence for a theatre or place of public amusement in the Federal Territory. Under the Private Employment Agencies Act 1981 (Act 246), whereby each private employment agency is to be licensed by the Director-General of Labour who can cancel the licence (under section 25) on certain grounds after giving an opportu- 


\section{MEDIA
HUKUM}

nity to the licensee to show cause. An appeal from the Director-General lies to the Minister whose decision is final. Adjudication by Ministers in the first instance also exits in relation cancellation of citizenship as stated in article 27 of the Federal Constitution.

\subsubsection{Administrative Decision, Inquiry and} Ombudsman: Royal Commission of Inquiry ( $\mathrm{RCl}$ )

The royal commission's powers are derived from the Commission of Inquiry Act 1950. The RCl reports directly to the Yang di-PertuanAgung (The King). It merely makes recommendations and findings based on its terms of reference and after considering the evidence. The government then decides on whether to give effect to the recommendations and findings of the $\mathrm{RCl}$. These recommendations and findings are not binding on the government and they do not have the force of law. They are subject to implementation or enforcement by the government. Therefore, the recommendations and findings of the $\mathrm{RCl}$, being non-binding in nature and not enforceable in law, cannot be termed as a decision that affects the rights of aggrieved or interested parties.

A few commissions have been established since the Independence to look into various important issues and events. Among the most notable is the Royal Commission of Inquiry into the Lingam Video Clip. The Royal Commission was formed in late 2007 to investigate into an allegation of illegal intervention into the judicial appointment process of Malaysian judges purportedly occurred in 2002. The formation of the commission was a follow-up to a recommendation by a three-man panel which was tasked to determine the authenticity of a video clip of a telephone conversation that raised the allegation. The allegation was first made public in September 2007 by former Deputy Prime Minister of Malaysia Anwar Ibrahim who released a low quality video showing lawyer V.K. Lingam allegedly talking to former Chief Judge of MalayaAhmad Fairuz Abdul Halim about the appointment of the latter into the office of Chief Justice of the Federal Court. Ahmad Fairuz retired as the Chief Justice of the Federal Court in late 2007.

In 2004 the Royal Commission for Police Reform was established. A 16-member Royal Commission to Enhance the Operations and Management of the Police Force was set up. It was headed by former chief justice Tun Mohamed Dzaiddin Abdullah. Former inspector-general of police Tun Mohammed Hanif Omar was its deputy chairman. The commission was tasked with rectifying weaknesses, improving work procedures and enhancing public confidence in the police. Prime Minister Datuk Seri Abdullah Ahmad Badawi, when proposing the commission, said he wanted to eradicate corruption, brutality and poor service in the force.

The Royal Commission to investigate alleged injuries suffered by Datuk Seri Anwar Ibrahim while in police custody was set up in 1999. The royal commission was formed to investigate alleged injuries suffered by Datuk Seri Anwar Ibrahim while in police custody. The commission was chaired by former chief judge of the High Court of Malaya Tan Sri AnuarZainalAbidin. Also on the panel were retired Court of Appeal judge Datuk Mahadev Shankar and Pantai Medical Centre consultant orthopedic surgeon Datuk Dr.Yeoh Poh Hong.

More recently Royal Commission of Inquiry into the Teoh Beng Hock case was establishedto look into the sudden death of political aide TeohBeng Hock while under the watch of the Malaysian Anti-Corruption Commission. He was a Malaysian journalist and political aide to Ean Yong HianWah, a member of the Selangor state legislative assembly and state executive council. On 15 July 2009, the Malaysian Anti-Corruption Commission (MACC) took Teoh into custody for questioning about allegations of corruption. Teoh was found dead the next morning on the rooftop of a building adjacent to the MACC offices.

Not very long ago the Royal Commission of Inquiry on illegal immigrants in Sabah was formed on 11 August 2012. The Royal Commission investigated the problems relating to citizenship and immigrants in the state of Sabah in Malaysia. The inquiry is closely related to Project IC, the alleged systematic granting of citizenship to foreigners.

In 1991 A Royal Commission of Inquiry was set up to look into the fire at the Bright Sparklers factory in Sungai Buluh New Village - the nation's worst industrial disaster, claiming 21 lives. Kuala Lumpur High Court judge Datuk Wan Adnan Wan Ismail was appointed chairman of the three-member panel. The Royal Commission had found the 
fireworks factory and fire which killed 22 people and injured 103 others. It concluded that Bright Sparklers Sdn. Bhd. Had violated many laws to carry out a dangerous operation, caused much human misery and that it must not escape prosecution. It also concluded that Bright Sparklers Sdn. Bhd. Was able to continue their illegal operation undetected for such a long time because certain government departments had failed to perform their duties properly as required under the various legislations pertaining to the siting, construction, maintenance and operations of the factory. The departments cited by the Royal Commission of Inquiry included the local authorities, the State Government, the Pharmacy Department and the Fire Services Department.

Other RCls which hads been established in relation to events of disasters include Royal Commission of Inquiry to investigate a fire at Sekolah Agama Rakyat Taufikah alHalimah in Padang Lumat, Yan, Kedah (1989) and Royal Commission of Inquiry on the collapse of the upper deck of the Pengkalan Sultan Abdul Halim ferry terminal in Butterworth (1988). A year earlier a Royal Commission of Inquiry was established by the Housing and Local Government Ministry to investigate a fire at Sekolah Agama Rakyat Taufikah al-Halimah in Padang Lumat, Yan, Kedah, which killed 27 schoolgirls. It was chaired by Tan Sri Abdul Aziz Zain. The Sultan Abdul Halim ferry terminal bridge collapse was a disaster of the Penang Ferry Service which occurred on July 31, 1988, at the Sultan Abdul Halim ferry terminal in Butterworth, Penang, Malaysia. The collapse caused the deaths of 32 people and injured 1,634 people. It was blamed on overcrowding and the jetty being made out of steel bars that led to the collapse.

Several RCls were commissioned to look into matters pertaining to public services. Apart from the Royal Commission for Police Reform mentioned above others are Royal Commission on the Teaching Services (1971), Royal Commission of Inquiry to Investigate the Workings of Local Authorities in West Malaysia (1968) and Royal Commission on Salaries and Conditions of Service of the Public Service (1965) (Royal Commission on the revision of salaries and conditions of service in the Public Services (Malaysia, 1969).

\subsubsection{Administrative Decision, Inquiry and Ombudsman: The Public Complaints Bureau [PCB]}

In Malaysia, the suggestion to have the Ombudsman has been discussed for a very long time; in fact, it was discussed even from the time of the late Tun Abdul Razak. On 23 July 1971, the Ombudsman system in the Malaysian version, which is the Public Complaints Bureau (PCB), was set up. It was placed under the Department of the Prime Minister. It gave the opportunity to the public to complain of their dissatisfaction against all aspects of administration of the government except any issues that have been determined as the policy and underlying principles of the government. In trying to improve the quality of government services, the public can take their grouses and put them to good use by lodging a complaint to the Public Complaints Bureau (PCB). It is a form of checks and balances for the people's interests. Its role is to receive second tier complaints. If the public is unhappy, they should first lodge the complaint with the agency itself for speedy resolution. If that avenue cannot be pursued, PCB will take up the matter.

PCB focused on two key aspects in handling public complaints namely to seek corrective action and preventive action. Corrective action is what needs to be corrected immediately. When the complaint is received, PCB would need to look at how to resolve the matter promptly.

Preventive action looks into how some recurring problem can be solved so that it does not repeat. Like counter services, it doesn't want the public to keep on complaining that a particular civil servant. Among the many objectives of this body are to resolve complaints efficiently, fairly, and effectively, improve the rate of resolving complaints received from the public, provide and improve facilities for the public to lodge complaints, reduce repetitive complaints against the public services, introduce changes and innovation based on public complaints received, provide advisory services to agencies in order to improve the effectiveness of public complaints management system, detect issues than can lead to complaints made by the public andobtain public opinion to ensure the success of the Governments. 


\section{MEDIA
HUKUM}

4.1.3. Administrative Decision, Inquiry and Ombudsman: The Malaysian Anti-Corruption Commission (MACC) (Formerly known as The Anti Corruption Agency [ACA])

In early 1959, Malaysia's (then Malaya) efforts to combat corruption were carried out by two entities, respectively focusing on investigations and prevention. Investigations on corruption cases were tasked to the Special Crimes Unit of the Criminal Investigation Department of the Royal Malaysian Police while an Anti-Corruption Agency was set-up in the Prime Minister's Department to manage the aspect on prevention. Matters related to prosecution were under the purview of the Attorney General's Chambers.

In view of the fact that anti-corruption activities were then carried out by three different agencies, the Government decided to consolidate the task of investigation, prevention and prosecution under one umbrella by setting-up the Anti-Corruption Agency (ACA) in 1967 in accordance with the Anti-Corruption Act 1967. In 1973, the ACA changed its name to the National Bureau of Investigations (NBI) in accordance with the passing of the NBI Act 1973, becoming a full-fledged department under the Home Ministry and with greater powers to investigate corruption cases including those of national interest. Subsequently, in a move to specialize the anti-corruption body in terms of its roles and functions, NBI was re-named back to ACA in 1982 with the passing of the ACA Act 1982 thus making ACA as a single and special entity in fighting corruption in Malaysia. The existence and operation of the long standing AntiCorruption Agency [ACA] was reiterated in the Anti-Corruption Act 1997 (Act 575). It must be noted that the final decision to prosecute an individual rests with the Public Prosecutor (National Integrity Systems, Country Study Report, Malaysia 2003. p.32 22 Section 50, Act 575.). The Public Prosecutor is the Attorney General, who is appointed by the Yang di-PertuanAgong (the King) on the advice of the Prime Minister. (The Public Prosecutor is the Attorney General who "shall have power, exercisable at his discretion, to institute, conduct or discontinue any proceedings for an offence, other than proceedings for an offence before a Syariah Court, a native court or a court martial." Article 145(3), Federal Constitution.).
In 2008, the Parliament and the Government unanimously approved the formation of an independent anti-corruption commission to be known as the Malaysian AntiCorruption Commission (MACC) and replacing the ACA Act 1982 to the MACC Act. The MACC Act 2009 came to effect on 1 January 2009 which led to the official establishment of the MACC as an independent, transparent and professional body to effectively and efficiently manage the nation's anti-corruption efforts.In moving towards convincing the public of the MACC's independency, transparency and professionalism, a 'Check and Balance Mechanism' was created through the formation of a five panel independent body to closely and constantly monitor the functions of the MACC. This 'check and balance mechanism' comprises of the Anti-Corruption Advisory Board (ACAB), the Special Committee on Corruption (SCC), the Complaints Committee (CC), the Operations Review Panel (ORP) and the Consultation and Corruption Prevention Panel (CCPP) that functions to advise as well as to ensure that the functions and roles of the MACC are implemented efficiently, effectively, independently, with transparency and professionally. Members of these bodies represent the general public and comprise of senior ex-government officials, politicians (government and opposition), professionals from the business and corporate sector, academicians, lawyers and well respected individuals.

\subsection{Arbitration}

Arbitration is a generic term for a voluntary process in which people in conflict request the assistance of an impartial and neutral third party to make a decision for them regarding contested issues. Arbitration is a quasi-judicial process in which people in a dispute present their views to one or more knowledgeable neutral people who decide how the dispute will be resolved. Arbitrators review evidence, hear arguments, and make a decisions, often in the form of a monetary "arbitration award" paid by one person to the other. Arbitration is generally a binding process, which means that the participants agree up front to abide by the arbitrators' decision. In "high/low" binding arbitration, the participants may negotiate in advance an upper and lower limit for the arbitrators' award (Conflict Resolution Terms and 
Processes.http://www.acrnet.org).

Arbitration is an alternative form of dispute resolution that is commonly used by businesses and other individuals before filing a lawsuit. It works in a manner similar to that of a formal trial, but the parties to the dispute present their case to a panel of arbitrators instead of to a judge or a jury. Most arbitrators are attorneys who practice in that jurisdiction. During an arbitration process, the arbitrators will listen to the parties' dispute, view their evidence and rule on the issue. Arbitration is considered to be "non-binding" in some jurisdictions, which means that the losing party is not obligated to comply with the ruling of the arbitrators. In such as case, the winning party will need to file a formal lawsuit and receive a subsequent judgment in that party's favor. Despite its informalities, arbitration is one of the most favored forms of dispute resolution because it saves each party the time and money that is required for litigation in a lawsuit.

\subsubsection{Arbitration in Malaysia: The Arbitration Act 2005}

On March 15, 2006, Law 646 of 2005, on Arbitration came into effect in Malaysia replacing and repealing the Arbitration of 1952. The 2005 Act seeks to reform the law relating to domestic arbitration, provide for international arbitration, and to provide for the recognition and enforcement of awards and for related matters. It seeks to promote international consistency of arbitral regimes based on the model law adopted by the United Nations Commission on International Trade Law (UNCITRAL) on 21 June 1985.

The 2005 Act adopts most of the broad principles outlined in the Model Law and fits in some of the more beneficial aspects of the existing common law systems of Malaysia. Section 51 (2) and (3), of the Arbitration Act 2005, provide that the Act does not apply to arbitral proceedings commenced before the coming into force of the Act which was the 14th of March 2006. Such arbitral proceedings will be governed by the Arbitration Act 1952. Among the principal features of the 2005 Act is the distinction between international and domestic arbitrations. An international arbitration is defined as that where one of the parties has its place of business outside Malaysia, or where the seat of the arbitration is outside Malaysia or where outside Malaysia the substantial part of the obligations of any commercial or other relationship is performed or the place where the subject matter of the dispute is most closely connected with. A domestic arbitration is defined as any arbitration which is not an international arbitration.

In respect of international arbitrations with Malaysia as the seat, Part III of the 2005 Act, which inter alia deals with consolidation of proceedings, powers of the High Court in determination of preliminary point of law and reference on questions of law arising out of an award, does not apply unless the parties agree otherwise in writing. For domestic arbitrations, Part III applies unless the parties agree otherwise. Simply put, if parties to an international arbitration want greater access to the Malaysian Courts they are free to include Part III. Conversely, parties to a domestic arbitration can curtail their right of greater access to the Courts by opting out of Part III. This "opting in" and "opting out" provision ensures that party autonomy is given due recognition.

\subsubsection{Arbitration in Malaysia: The Kuala Lumpur Regional Centre for Arbitration}

The Kuala Lumpur Regional Centre for Arbitration (KLRCA) was established in 1978 under the auspices of the international governmental international law body, the Asian-African Legal Consultative Organization (AALCO), to provide a forum for the settlement of disputes by arbitration in trade, commerce and investment within the Asia-Pacific region. While it has the support of the Malaysian government, KLRCA is a non-profit organization and is not a branch or agency of the government. Kuala Lumpur Regional Centre for Arbitration Rules (KLRCA Rules) adopts the latest UNCITRAL Arbitration Rules 2010 with modifications. KLRCA Rules allows a great deal of flexibility in the conduct of proceedings of the arbitration and leaves a wide discretion to the parties with regard to the choice of arbitrators, the place of arbitration and the applicability of the procedural rules.

\subsection{INFORMAL NON-LEGAL MEANS}

This category refers to method which involved people or party not created or empowered by law to make legally 


\section{MEDIA
HUKUM}

binding decision. The people involved in the process mainly assist the conflicting parties to find ways to settle dispute and settle their grievances.

\subsection{Negotiation/ Discussion}

When avoidance is no longer possible or tensions become so strong that the parties cannot let the disagreement continue, they usually resort to informal problem-solving discussionsto resolve their differences. Negotiation, sometimes called "direct" or "unassisted" negotiation, refers to any dialogue involving two or more people in an effort to resolve a dispute or reach an agreement. People negotiate all the time, and negotiation is often the first step in attempting to resolve disputes. However, people also can and do seek relief from the court system or from other dispute resolution processes without first attempting to negotiate with one another. People may also choose to have a lawyer or other expert to negotiate on their behalf (Conflict Resolution Terms and Processes. http://www.acrnet.org).

\subsection{Conciliation}

Conciliation is a process in which a neutral person functions as a "go between" in an attempt to resolve a dispute involving two or more people. The conciliator may have multiple private conversations with the people in dispute in hopes of identifying shared interests and reaching an agreement that meets the needs of the participants and resolves their dispute. The conciliator does not generally bring the people in dispute together or create an opportunity for them to talk directly to each other. The conciliator must remain neutral and has no decision making authority (Conflict Resolution Terms and Processes. http://www.acrnet.org).

\subsection{Mediation}

Mediation is a process in which one or two neutral mediators help people in a dispute to communicate with one another, understand each other, and if possible, reach agreements that satisfy the participants' needs. Mediators do not provide legal advice or recommend the terms of an agreement. Instead, the mediator helps people reach their own agreements, rebuild their relationships, and, if pos- sible, find lasting solutions to their disputes. In mediation, people speak for themselves and make their own decisions. Participants in mediation may or may not be represented by counsel (Conflict Resolution Terms and Processes. http:// www.acrnet.org). It is the most casual legal form of dispute resolution. A mediator is an individual who works with both parties to a dispute in the hopes of bringing the parties together to reach an agreement. The mediator generally makes suggestions and recommendations to the disputing parties, but those suggestions and recommendations are not binding upon the parties.

In some countries, mediation is available in the private sector, through community-based mediation services, and in courts. At some community programs, trained volunteer mediators are assigned to each case. In the private market, people select their own mediators usually based on the mediators background and experience. In most court programs, a mediator will be assigned to a case (Conflict Resolution Terms and Processes. http://www.acrnet.org).

\subsection{Settlement Conference}

Settlement conference refers to a process in which people in a dispute in court present their views to a knowledgeable neutral person who evaluates their case and suggests ways to settle it without trial. The settlement conference facilitator is usually a judge or experienced lawyer who is able to give informed opinions about how the court might decide the case, to indicate how similar cases have been settled, to provide advice, and to suggest the terms of an agreement (Conflict Resolution Terms and Processes. http:// www.acrnet.org).

\subsection{Consensus Building}

Consensus Building is a process in which a neutral person brings stakeholder groups and individuals together and facilitates their efforts to solve a problem or address a complex issue in a way that best meets the participants' needs. Consensus building resembles mediation because the process is about people making their own decisions, opening lines of communication, and developing agreements that everyone can support. Consensus building, however, usu- 
ally involves a much larger group of people than can be accommodated in mediation and is generally used to prevent or resolve disputes about public policy or other complex issues affecting many people (Conflict Resolution Terms and Processes. http://www.acrnet.org).

\subsection{Community Conferencing / Mediation}

Community conferencing or community mediation is a process in which a neutral person brings together everyone in a community who as been affected by an action resulting in serious harm. During the meeting, the participants hear what happened, talk about how they have been personally affected, and work together on a plan to repair the harm. Although most frequently used in response to incidents of crime and delinquency, the process can be used for a wide variety of community conflicts.

\subsection{INFORMAL NON-LEGAL MEANS IN MALAY- SIA}

Mediation as an informal non-legal means to solve dispute has long been embraced in Malaysia as a form of alternative dispute resolution (ADR). Several professional institutions such as the Malaysian Mediation Centre and the Chartered Institute of Arbitrators provide mediation services using their respective codes of ethics and rules. Only selected mediations bodies and institutions are discussed below.

\subsection{The Mediation Act 2012}

The Mediation Act 2012 was introduced by Parliament, and came into force on Aug 1, 2012 with the aim of promoting and encouraging mediation as a method of ADR and to facilitate the settlement of disputes in a fair, speedy and cost-effective manner. "Mediation" is defined under the Act to mean a voluntary process in which a mediator facilitates communication and negotiation between parties to assist them in reaching an agreement. The Act does not apply to: (1) mediation conducted by courts; (2) mediation conducted by the Legal Aid Department; and (3) matters expressly excluded in its schedule (such as proceedings on the Federal Constitution, the remedy of temporary or per- manent injunctions, and any criminal matter). The Act does not oblige parties to mediate before litigation or arbitration. Also, parties may choose to mediate simultaneously with any civil court action or arbitration. Where proceedings have already commenced, mediation does not act as a stay or extension of proceedings.

The introduction of the Act is a step in the right direction. However it has been widely seen as being merely a reproduction of existing procedural rules of certain professional mediation institutions. The Act however has not addressed issues pertaining to regulation of the practice and accreditation of mediators. Stakeholders familiar with the mediation framework in Malaysia have long hoped for legislation to regulate the practice of mediation by mediators and the standardization of competency requirements with minimum qualifications for mediators, whether or not through an accreditation system where an authority is given the power to revoke or confer accreditation.

\subsection{Mediation by Local Traditional Chiefs / Local Religious Leaders}

A study on this type of mediation has been conducted by James A. Wall Jr. and Ronda Roberts Callister. The study investigates the mediations of 127 village leaders (ketuakampungs) and 52 religious leaders (imams) in Malaysia. These mediators rely heavily on techniques of meeting with disputants (separately and together), listening to the disputant's side, information gathering, and calling for concessions. They also use three distinct strategies: a "meet separately" strategy, an assertive strategy, and a strategy based on information gathering. The imams rely more on prayer, moral principles, listening, and third-party advice and call less often for concessions. Imams use a unique "meet together" strategy and prayer strategy.

\subsection{Financial Mediation Bureau (FMB)}

The Financial Mediation Bureau is an independent body set up to help settle disputes between individual and the financial services providers who are members of the FMB. It is an integrated dispute resolution centre for financial institutions. It provides free avenue to refer disputes for reso- 


\section{MEDIA
HUKUM}

lution as an alternative to the courts. These disputes may be Banking/Financial related as well as Insurance and Takaful related. The FMB provides an avenue of redress for a wider spectrum of the public since it covers the consumer areas of Islamic insurance, development finance institutions, as well as non-bank issuers of credit and charge cards.

\subsection{Malaysian Mediation Centre (MMC)}

It is established under the auspices of the Bar Council with the objectives of promoting Mediation as a means of alternative dispute resolution and to provide a proper avenue for successful dispute resolution. The ADR Committee of the Bar Council is responsible for the proper functioning and implementation of the Centre's objectives. The Centre offers mediation services and providesassistance and advice on how to get the other side to agree to mediation if one party has shown interest. It also provides mediation training for those interested in becoming mediators and accredits and maintains a panel of mediators. Currently the Centre accepts civil, commercial and matrimonial matters and intends to expand the scope to other matters at a later stage. Mediators of the Centre are subject to a code of conduct which provides for a strict compliance of impartiality and confidentiality.

\subsection{Court - Annexed Mediation}

The court-annexed mediation program is a free mediation program using judges or other agreed person as mediators to help disputing parties in litigation to find a solution. It is a service provided by the judiciary as an alternative to a trial which is a win-lose proposition.

The Chief Justice of Malaysia has issued a Practice Direction on mediation, which came into effect on 16 Aug 2010. According to the Practice Direction, all Judges of the High Court and its Deputy Registrar and all Judges of the Sessions Court and Magistrates and their Registrars, may "give such directions that the parties facilitate the settlement of a matter before the court by way of mediation". The objective of this Practice Direction is to encourage parties to arrive at an amicable settlement without having to go through, or complete, a trial or appeal. The Practice
Direction offers the following modes of referrals to mediation, whereby parties are given the option to select either Judge-led mediation or a mediator agreeable to by both parties.

Among the benefits of settling disputes by way of mediation are parties are able to explore all options available; underlying issues and common grounds may be identified; good relationships are restored and maintained; terms agreed upon would be acceptable to both parties; settlement is expeditious; no delays in court hearings; and terms of settlement are final.

\section{CONCLUSION}

In every society a large number of legal and non-legal, formal and informal, contemporary and customary principles, methods and institutions exist to rectify wrongs and promote remedies. Litigation is only one choice amongst many viable alternatives. The constitutional framework of Malaysia has allowed the various ADR means and institutions to flourish There is a range of dispute resolution mechanisms available of which the formal justice system and alternative dispute resolution are but two examples. The demands of substantive and procedural justice are so monumental and multi-dimensional that no law, no single institution and no one method is adequate to the task. When the society has doubt over the integrity and independence of the judiciary, there is a real danger of chaos because members of the public will lose faith in the ability of the justice system to resolve disputes. This can lead to citizens taking the law into their own hands, which at its worst can lead to fear and open violence. The people will feel insecure and might take justice in their own hands. In order to prevent such situation from happening there must be reliable channels outside the formal justice system for the people to address their complaints, grievances and sorrow. Various alternative dispute resolutions could be deployed, as have been discussed above, to provide peaceful means in tackling the problems. The various legal and non-legal means in Malaysia have supplemented the role of judiciary in providing justice and addressing sensitive matters and controversial issues in the country. These methods have proved to be significant and useful in defusing tensions. Thus there is a 
need to strengthen non-legal, informal, expeditions and inexpensive remedies for solving grievances; to supplement court-processes with the widest range of ADR techniques. The sense of community, harmony, trust and reciprocity need to be revived and it is also important to involve village elders, community leaders and mosque officials in informal, neighborhood tribunals to smooth away discords and to make justice accessible to all. The key to the success is commitment and support provided by the government to all actors and institutions involved. In order to maintain their integrity and efficiency the authority should provide sufficient legal protections and safeguards as well as financial stability and adequate manpower and facilities. These is important in order to enable justice is accessible to all. Justice is dead if it is inaccessible. Without institutions and mechanisms that dispense and enforce justice, rights and freedom are only illusions.

\section{BIBLIOGRAPHY}

Crocker, C., \&Hampson, F.O. (Eds.).Managing Global Chaos: Sources of the Response to International Conflict (Washington, US Institute of Peace Press, 1996)

KasukaMutukwa, Parliament's Role In Conflict Mediation/ Resolution, Policy Dialogue On Legislative Development, 20-22 November 2002: Brussels.

Leiser, B., Liberty, Justice and Morals (New York, The MacMillan Company, 1973)

National Integrity Systems, Country Study Report, Malaysia 2003.

Pirie, A., Alternative Dispute Resolution: Skill, Science and the Law (Toronto, Irwin Law, 2000)

Royal Commission on the revision of salaries and conditions of service in the Public Services (Malaysia), Kuala Lumpur: JabatanChetakKerajaan, 1969.

Schapiro, M., Courts: A Comparative and Political Analysis (Chicago and London, The University of Chicago Press, 1981).

Tidwell, A.,Conflict Resolved? (London, Printer, 1999)

Federal Constitution.

Alan Simpson, The Role of Law in Conflict Management at website Mediate.com, www.mediate.com

Conflict Resolution Terms and Processes.http:// www.acrnet.org

National Alternative Dispute Resolution Advisory
Council, Issues Of Fairness And Justice In Alternative Dispute Resolution, Canberra, November 1997, as in website of Attorney-General's Department, Government of Australia, https://www.ag.gov.au.

Robert H. Mnookin, Alternative Dispute Resolution, March 4, 1998 as in http://www.law.harvard.edu 